\title{
Teaching
Methods
}

\section{Integrating Horticulture Biology and Environmental Coastal Issues into the Middle School Science Curriculum}

\author{
Kathryn Karsh ${ }^{1,3}$, Edward Bush ${ }^{1}$, Janice Hinson ${ }^{2}$, \\ and Pamela Blanchard ${ }^{2}$
}

ADDITIONAL INDEX WORDs. stewardship, grade-level expectations, wetlands

SumMARY. Encouraging students to become better stewards of the environment and to be more educated in science content knowledge is an important goal of today's educational leaders. Eight lessons were created to aid an established stewardship program (Coastal Roots) in introducing hands-on activities to middle school children in southern Louisiana. Students were tested on science content in the lessons using a pre-test, eight multiple choice quizzes (each focusing on a particular lesson), and a post-test. The "children's attitudes toward the environment scale" test was administered to evaluate environmental awareness changes in the treatment and control group students. Students who received the horticulture lessons improved their post-test scores by 11.4 points $(P \leq 0.05)$ in the first year and 25.07 points $(P \leq 0.0001)$ in the second year of the study. Significant increases in individual lessons were found both years. In the second year, students who received the lessons were more aware of their role in the environment than those who did not receive the additional lessons $(P \leq 0.01)$. The addition of horticulture lessons to the middle school curriculum enhanced student knowledge and stewardship of the environment.

$\mathrm{I}$ $t$ is essential that environmental education be integrated into the science classroom. Many educators use environmental education to enhance student science-based knowledge. Studies have shown that introducing environmental education not only raises science scores, but other subject scores as well (Wakefield, 2001 ), therefore the use of environmental education in the classroom maybe an excellent strategy to obtain

${ }^{1}$ Department of Horticulture, 137 JC Miller Hall, Louisiana State University, Baton Rouge, LA 70803

${ }^{2}$ Department of Educational Theory, Policy, and Practice, Peabody Hall, Louisiana State University, Baton Rouge, LA 70803

${ }^{3}$ Corresponding author. E-mail: kkarsh1@lsu.edu. student interest and increase student knowledge of all subject areas. The Louisiana Sea Grant College Program (Sea Grant) has taken this idea and put it into action. In 1999, Sea Grant established an educational program entitled "Coastal Roots" (Blanchard, 2007). Coastal Roots teaches information on Louisiana's wetland loss to elementary through high school students and fosters stewardship for the state's coastal resources. Coastal Roots combines nursery management and coastal environmental awareness into a hands-on program. Participating schools grow coastal plants for local wetland restoration projects. A $10 \times 10$-ft can yard is set up at each school and is used as a growing area for the student's seedlings. Coastal Roots students are responsible for the health and progress of their seedlings from seed to a finished product. As the plants mature, the students take the coastal plants to an area near the school that is in need of restoration. The students plant the seedlings and, in some cases, track the growth of the coastal trees and shrubs. While Coastal Roots provides excellent activities to foster students' love for the wetlands, it was in need of an in-class, environmental education component. Because Coastal Roots is a nurserybased program teaching students to raise wetland plants for restoration projects, it was decided that horticulture-based lessons should be developed to accompany this program. The horticulture lessons were designed to teach students the basic needs and processes of plants, as well as the benefits of plants. More importantly, the lessons take this basic horticulture knowledge a step forward, and introduce the importance of plants to Louisiana's wetlands. Coastal Roots and other environmental education programs are imperative to enhancing students' science-based knowledge. These programs not only benefit teachers and the educational system, but also help train and educate a volunteer base to help combat the loss of Louisiana's wetlands. Louisiana is currently facing major coastal land loss due to erosion from hurricanes and subsidence. Not only will the land loss lead to destruction of habitat of many of our native plants and animals, but it will also impact the recreation and economic revenues Louisiana receives each year. To combat such as loss without major expenses, Louisiana will need to recruit a large number of volunteers to grow and maintain coastal plants for restoration and teams to do the actual planting of the coastal plants. The most effective volunteers would be educated in coastal studies and plant science. Therefore, eight horticulture-based lessons were developed and tested on experimental and control students in participating in Coastal Roots schools during the 2003-04 and 2004-05 school years.

Several studies have been conducted to determine a potential correlation between integrating nature in the classroom and improved science scores of students. Pivnick (1994) 
thought that more than the lessons themselves, the school gardens help students feel closely connected to nature, and that this connection to nature instills a deep environmental ethic in students.

Klemmer's (2002) study determined whether or not the use of a garden aided in improving student science scores. Teachers used the Texas Junior Master Gardening Handbook as a resource and used gardens within the science curriculum. Test results indicated that students in experimental groups in third through fifth grades had higher scores than those students who did not participate in the study.

Smith (2003) conducted a study using several lessons from the Texas Junior Master Gardener Handbook to determine if students receiving these additional lessons scored higher on science achievement-based tests. In Smith's study, an analysis of variance (ANOVA) indicated that gender had no significant effect on student scores. Her experimental student group scored statistically higher $(P \leq 0.05)$ on the post-test in comparison with the pre-test, averaging $39 \%$ on the pre-test and $42 \%$ on the post-test. The control student test scores (students without the Junior Master Gardener lessons) did not statistically increase from pre- to post-test.

Judith Brough, from Gettysburg College, found that the average attention span of a student in middle school is $11 \mathrm{~min}$ in a 50 - to 60 -min class period (Longert, 2004). This study was unique in that it did not involve a school garden, but rather hands-on activities inside the classroom that bring nature indoors. Taking the knowledge gained from each of the above studies, we hoped to improve student's science-based knowledge by introducing nature to the classroom through a variety of hands-on, auditory, and visual activities.

\section{Materials and methods}

Participants. Four southern Louisiana schools participated in this study. The schools were chosen from those schools that were currently participating in the Coastal Roots program. One private and three public schools in four southern central parishes (counties) participated. In the 2003-04 school year, 275 students participated, ranging from the sixth to ninth grades. In the 2004-05 school year, 188 students participated, ranging from the sixth to seventh grades. Students participating in the second year of this study were not the same students as those who participated in the first year of the study.

Experimental and control groups were established at each school. The experimental groups (Group A) received eight additional targeted horticulture lessons, lesson quizzes, all pre- and post-tests, and the pre- and post- "children's attitudes toward the environment scale" [CATES (Musser and Malkus, 1994)]. The control group (Group B) did not receive any of the additional horticulture lessons or quizzes. Group B only received the pre- and post-horticulture test and the pre- and post-CATES.

Lessons. Eight l-h lessons were taught monthly during each school year to the Group A students. Group B students were not taught the lessons. Lesson topics included plant structures and plant identification; wetland habitats; photosynthesis; composting; plant pollination; plant genetics; wetland soils; and global climate changes and the greenhouse effect. All lessons were developed by K. Karsh and E. Bush at Louisiana State University with the exception of the wetland habitats, wetland soils, and global climate changes lessons, which were modified from "WOW! Wonders of Wetlands" curriculum.

The topics were selected based on Louisiana's state-mandated curriculum and the Louisiana Grade-Level Expectations (GLEs) and the needs of the Coastal Roots program (Louisiana Department of Education, 2004). Each horticulture lesson targeted two to four GLEs in the seventh grade science category. The horticulture lessons targeted a total of 26 of the 43 seventh grade science GLEs. Each lesson was divided into two to three separate activities. The horticulture lessons included projects that use visual, auditory, and handson learning techniques. Materials that were needed to teach each lesson were provided to the participating classes free of charge. Sponsors for materials were the Louisiana State University Department of Horticulture, the Louisiana Sea Grant College Program, and a Captain Planet Foundation grant.

Several modifications were made in how the lessons were taught between year 1 and year 2. The lessons were all taught by K. Fontenot, who was the principal investigator in this study. After the lesson was given, the "regular" science teacher for each class filled out an evaluation form detailing administration of the lesson and activities within the lesson. Suggestions from those evaluations were taken into consideration for the second year. Most of the suggestions included ending each lesson with a summary of what the students learned; allowing students ample time for each individual activity in the lesson, even if it meant that the science teacher would finish the lesson the following day; and writing the main points of each lesson on the board for the students to see while the lesson was being taught.

Testing. Group A and Group B students received a general horticulture test at the beginning of the school year; this was considered the horticulture pre-test. The same test was given to Group A and Group B at the end of the school year; this was considered the horticulture post-test. The horticulture pre- and post-test was designed to determine student horticulture knowledge before and after the program. The 2003-04 horticulture pre-test and post-test consisted of 30 multiple choice questions. In the 2004-05 school year, the test was modified to better assess test takers' knowledge and it consisted of 32 multiple choice questions. The number of questions was modified to ensure that each lesson was equally tested, therefore two questions were added to the modified test in year 2 to allow each of the eight lessons to be represented by four questions on the test. In addition to a horticulture pretest and post-test, Group A and Group B students took a pre-CATES and post-CATES. The CATES was used to determine the change in environmental stewardship of students. The CATES should be a good indicator of environmental stewardship changes within Group A and Group B students, as many educators believe that introducing nature into the classroom enhances student appreciation for nature. In addition to the horticulture pre- and post-test and pre- and post-CATES, Group A students were given a short multiple choice quiz at the end of each lesson. The questions on the quizzes were 
statistically compared with the posthorticulture test questions to analyze student's short- and long-term memory retention of the introduced horticulture topics. Group B students were not given the individual quizzes or horticulture lessons.

Horticulture pre- and post-tests for the first year of study were compared statistically using paired $t$ test and ANOVA. Using both tests, differences were analyzed by school, gender, treatment, and grade-level. The post-horticulture test score was analyzed using paired $t$ test and ANOVA against each individual short-term memory quiz for Group A students only. Statistically comparing the individual lesson quizzes and answers from the post-horticulture test enabled us to analyze the student's ability to retain the taught information in their short- and long-term memories. The CATES was statistically analyzed using ANOVA. During the 2004-05 school year, horticulture pre- and post-tests were analyzed using paired $t$ test and ANOVA as completed in the first year. The second year tests scores were not compared with first year test scores as lessons were modified to better suit the learning styles and needs of participating students. The lesson content quizzes were compared with answers from the horticulture posttest using a paired $t$ test and ANOVA. The CATES survey was statically analyzed using ANOVA in the second year of study.

\section{Results and discussion}

YeAr 2003-04. Group A students scored statistically higher $(P \leq$ 0.05 ) on the horticulture post-test (Table 1). Group A students improved their horticulture knowledge on average 11.4 points from the horticulture pre-test to the horticulture post-test (data not shown). Group B student knowledge improved by only 4.5 points from the horticulture pre-test to the horticulture post-test.

Each question on the pre- and post-horticulture test pertained to a specific lesson. After comparing the individual questions pertaining to each lesson, we were able to identify individual lessons the students improved upon from the pre- to post-horticulture tests. Statistically

Table 1. Average horticulture pre-test and post-test scores (based on a total score of $100 \%$ ) in 2003 and 2004 of students who participated in additional horticulture lessons (Group A) compared with those students who did not participate in additional horticulture lessons (Group B). The test was an assessment of student knowledge pertaining to horticulture topics relating to corresponding Louisiana state-mandated curriculum.

\begin{tabular}{lcc}
\hline Students $^{\mathrm{z}}$ & Pre-test average (\%) & Post-test average (\%) \\
\hline Group A & $35.9^{\mathrm{y}}$ & 47.3 \\
Group B & 36.2 & 40.7 \\
Significance & NS & $* * * *$ \\
\hline
\end{tabular}

${ }^{\mathrm{z}}$ Group A students were taught eight additional horticulture/wetland lessons throughout the school year. Group $\mathrm{B}$ students did not participate in additional lessons.

${ }^{y}$ Mean scores on horticulture pre-test and post-tests using a paired $t$ test $(\mathrm{n}=275)$; Ns, ${ }^{* * *}=$ not significant or significant at $P \leq 0.0001$ significant improvements were found for lessons on plant identification, photosynthesis, composting, wetland soils, and the total score on the posttest. The lesson differences found between the horticulture pre- and posttests were obtained by using a paired $t$ test and ANOVA comparing the scores from Group A students to Group B students. Plant identification, photosynthesis, and compost lessons were significant at $P \leq 0.05$. The wetland soils lesson and the total score were significant at $P \leq 0.01$ (Table 2). There were no significant differences found in gender, gradelevel, or school during the first year of the study.

Group A students had no significant difference in their pre- and posttest results for the plant genetics lesson. This indicates that Group A students were able to retain the information taught in the plant genetics lesson as well at the end of the school year as they did immediately after the lesson was given. Because of this result, we modified the design of lessons in the 2003-04 school year to match the style of the plant genetics lesson in the 2004-05 school year. The modifications to the lessons in year 2 were done to help students retain the information taught over the long term. There were no significant differences found on the CATES scale between Group A and Group B students in the first year of study (200304) data not shown.

YeAR 2004-05. Group A students scored significantly higher than Group B students on the posthorticulture test (Table 3 ).

Group A students had an average increase of 25.07 points from the preto post-test. Group B student scores

Table 2. Average treatment (Group A) and control (Group B) student scores (based on a total score of $100 \%$ ) in 2003 and 2004 on horticulture post-test questions pertaining to eight individual lessons. Each individual lesson was represented by four questions on the horticulture post-test. A significant difference between student groups indicates that that particular lesson aided in increasing student knowledge of Louisiana state-mandated curriculum pertaining to that particular horticulture topic.

\begin{tabular}{|c|c|c|c|c|c|c|c|c|c|}
\hline \multirow[b]{3}{*}{ Students $^{\mathrm{z}}$} & \multicolumn{9}{|c|}{ Lessons } \\
\hline & $\begin{array}{c}\text { Plant } \\
\text { identification }\end{array}$ & Habitats & Photosynthesis & Compost & Pollination & Genetics & $\begin{array}{c}\text { Wetland } \\
\text { soils }\end{array}$ & $\begin{array}{c}\text { Global climate } \\
\text { change }\end{array}$ & $\begin{array}{l}\text { Total } \\
\text { Score }\end{array}$ \\
\hline & \multicolumn{9}{|c|}{$(\%)$} \\
\hline Group A & $42^{y}$ & 50 & 63 & 37 & 27 & 66 & 51 & 45 & 47 \\
\hline Group B & 34 & 54 & 56 & 31 & 25 & 60 & 40 & 43 & 41 \\
\hline Significance & * & NS & * & * & NS & NS & $\star *$ & NS & ** \\
\hline
\end{tabular}

${ }^{\mathrm{z}}$ Group A students were taught eight additional horticulture/wetland lessons throughout the school year. Group B students did not participate in additional lessons.

${ }^{y}$ Mean score within columns on horticulture post-test $(\mathrm{n}=275)$ was determined by analysis of variance; Ns, ${ }^{*},{ }^{* *}=$ not significant or significant at $P \leq 0.05$ and $P \leq 0.01$, respectively. 
Table 3. Average scores (based on a scale of 100\%) in 2004 and 2005 of students who participated in eight additional horticulture lessons (Group A) compared with those students who did not participate in eight additional horticulture lessons (Group B) on the horticulture pre-test and post-test. The horticulture pre-test and post-test assessed student knowledge of Louisiana state-mandated horticulture topic curriculum.

\begin{tabular}{lcc}
\hline Students $^{\mathrm{z}}$ & Pre-test average (\%) & Post-test average (\%) \\
\hline Group A & $40.5^{\mathrm{y}}$ & 63.0 \\
Group B & 34.6 & 38.0 \\
Significance & NS & $* * * *$ \\
\hline
\end{tabular}

${ }^{\mathrm{z}}$ Group A students were taught eight additional horticulture/wetland lessons throughout the school year. Group B students did not participate in additional lessons.

${ }^{y}$ Mean score on the horticulture pre-test and post-test within columns were determined using a paired $t$ test $(\mathrm{n}=188) ; \mathrm{Ns},{ }^{* * *}=$ not significant or significant at $P \leq 0.0001$.

increased by an average of 3.36 points from the pre- to post-test. This finding indicates that the introduction of the additional horticulture lessons to the science curriculum significantly $(P \leq 0.0001)$ increases student knowledge of state-mandated science expectations.

Group A students scored statistically higher $(P \leq 0.001$ and $P \leq$ 0.0001 ) than Group B students in every individual lesson on the posttest (Table 4). This is an important improvement from the 2003-04 school year, where we found no difference in pre- and post-horticulture test scores between Group A and Group B students for the wetland habitat, pollination, plant genetic, and global climate change lessons. This result indicates that the students receiving additional horticulture lessons (Group A) improved their knowledge in state-mandated science curriculum for all areas of this study when compared with the Group B students.

There was no statistical difference in the pre- or post-test scores for the plant genetics or wetland soils lesson for Group A students (Table 5). This was an important finding, as the modifications in teaching styles of lessons between year 1 and year 2 enabled us to help students retain the information in these two lessons at the end of the school year.

Group A students scored statistically higher than Group B students on the CATES (Table 6). This finding indicates that the modified lessons taught to the Group A students helped ingrain a certain sense of environmental responsibility or awareness of the environment into the Group A students when compared with the Group B students. The differing CATES results between year 1 and year 2 can be explained by several changes in the study, with the most important being that in year 2 , the lessons were modified to better target student's attention and learning styles. This modification may have made the students interaction with nature through the horticulture lessons an easy and enjoyable interaction, thus increasing their environmental stewardship. In

Table 4. Average treatment (Group A) and control (Group B) student scores (based on a total score of $100 \%$ ) in 2004 and 2005 on horticulture post-test questions pertaining to eight individual lessons. Each individual lesson was represented by four questions on the horticulture post-test. A significant difference between student groups indicates that that particular lesson aided in increasing student knowledge of Louisiana state-mandated curriculum pertaining to that particular horticulture topic.

\begin{tabular}{|c|c|c|c|c|c|c|c|c|}
\hline \multirow[b]{3}{*}{ Students $^{\mathrm{z}}$} & \multicolumn{8}{|c|}{ Lessons } \\
\hline & $\begin{array}{c}\text { Plant } \\
\text { identification }\end{array}$ & $\begin{array}{l}\text { Wetland } \\
\text { habitats }\end{array}$ & Photosynthesis & Compost & Pollination & $\begin{array}{c}\text { Plant } \\
\text { genetics }\end{array}$ & $\begin{array}{l}\text { Wetland } \\
\text { soils }\end{array}$ & $\begin{array}{l}\text { Global climate } \\
\text { change }\end{array}$ \\
\hline & \multicolumn{8}{|c|}{$(\%)$} \\
\hline Group A & $59^{y}$ & 69 & 64 & 56 & 75 & 62 & 66 & 49 \\
\hline Group B & 43 & 40 & 47 & 31 & 54 & 42 & 41 & 23 \\
\hline Significance & $* * * *$ & $* * * *$ & $* * * *$ & $* * * *$ & $* * * *$ & $* * * *$ & $* * * *$ & $* * * *$ \\
\hline
\end{tabular}

${ }^{\mathrm{z}}$ Group A students were taught eight additional horticulture/wetland lessons throughout the school year. Group B students did not participate in additional lessons. ${ }^{y}$ Mean score on horticulture post-test within columns was determined using both a paired $t$ test and an analysis of variance $(\mathrm{n}=188) ;{ }^{* * *}=\operatorname{significant}$ at $P \leq 0.0001$.

Table 5. Group A students (those who participated in additional horticulture lessons) scores in 2004 and 2005 on individual lesson quizzes (a quiz given immediately after the lesson was taught) compared with their scores on questions pertaining to individual lessons on the horticulture post-test (given at the end of the school year). All scores were based on a total score of $100 \%$. Those lessons that had no significant difference between the quiz average and post-test average were retained in the student knowledge.

\begin{tabular}{|c|c|c|c|c|c|c|c|c|}
\hline \multirow[b]{3}{*}{ Test time $^{\mathrm{z}}$} & \multicolumn{8}{|c|}{ Lessons } \\
\hline & $\begin{array}{c}\text { Plant } \\
\text { identification }\end{array}$ & $\begin{array}{l}\text { Wetland } \\
\text { habitats }\end{array}$ & Photosynthesis & Compost & Pollination & Genetics & $\begin{array}{l}\text { Wetland } \\
\text { soils }\end{array}$ & $\begin{array}{l}\text { Global climate } \\
\text { change }\end{array}$ \\
\hline & \multicolumn{8}{|c|}{$(\%)$} \\
\hline Lesson quiz & $84.7^{\mathrm{y}}$ & 77.1 & 84.4 & 68.8 & 84.1 & 65.4 & 70.2 & 74.0 \\
\hline Post-test & 58.7 & 69.4 & 64.1 & 56.3 & 74.7 & 68.2 & 65.6 & 48.8 \\
\hline Significance & $* * * *$ & $* * *$ & $* * * *$ & $* * * *$ & $* * * *$ & NS & NS & $* * * *$ \\
\hline
\end{tabular}

${ }^{2}$ Test time refers to when the test was given. The lessons quiz was always given immediately after the lesson was taught. The post-test was given at the end of the school year. The post-test included questions covering all eight lessons taught throughout the school year. However, the average score in each column reflects only those questions on the posttest referring to a particular lesson.

${ }^{y}$ Mean test score within columns were determined using a paired $t$ test; Ns, ${ }^{* *}{ }^{*},{ }^{* * *}=$ not significant, $P \leq 0.001$, or $P \leq 0.0001$, respectively. 
Table 6. A comparison of average presurvey and post-survey scores in 2004 and 2005 of Group A (taught additional horticulture lessons) and Group B students (not given additional horticulture lessons) on the "children's attitudes toward the environment scale" (CATES) a survey that measures environmental stewardship.

\begin{tabular}{lcc}
\hline Students $^{\mathrm{z}}$ & Pre-test average $(\mathbf{1 - 4})$ & Post-test average $(\mathbf{1 - 4})$ \\
\hline Group A & $2.61^{\mathrm{y}}$ & 2.78 \\
Group B & 2.53 & 2.50 \\
Significance & $\mathrm{NS}$ & $* *$ \\
\hline
\end{tabular}

${ }^{\mathrm{z}}$ Group A students were taught eight additional horticulture/wetland lessons throughout the school year. Group $\mathrm{B}$ students did not participate in the additional lessons.

'Mean score on CATES within columns was determined using an analysis of variance; Ns, ** (not significant or significant at $P \leq 0.01$ ). CATES scale range is 1 to 4 , where $1=$ not environmentally friendly and $4=$ completely environmentally friendly.

addition, the second time that the horticulture lessons were taught, the instructor had more experience with the lessons and completing the lessons with groups of students.

There are many improvements that could be made to this study. Additional students could be added to both groups. The best way to make such a change would be to increase the test population size to one participating school in each parish in Louisiana. This would increase the number of pilot schools from 4 to 64. Louisiana's Department of Education also mandates that each student in Louisiana pass a Louisiana Educational Assessment Program (LEAP) test to pass onto the next grade level at certain grade levels. It would be beneficial to our study to compare and contrast Group A student scores on the LEAP to Group B student scores on the LEAP. This would give the horticulture lessons more credibility with the Louisiana's Department of Education. Even so, this study did statistically show that the addition of the horticulture lessons statistically improved student post-horticulture scores and environmental stewardship as determined by the horticulture test and CATES scores.

\section{Literature cited}

Blanchard, P.B. 2007. Coastal Roots: A pre-college plant-based stewardship pro- gram to connect students with coastal issues. Plant Sci. Bul. 54:138-146.

Klemmer, C. 2002. Growing minds: The effect of school gardening programs on the science achievement of elementary students. Texas A\&M University, College Station, PhD Diss.

Longert, S. 2004. How to: Adjust your teaching style to your student's learning style. 29 Dec. 2007. <http://teachersnetwork. org/ntol/howto/adjust/management. htm>.

Louisiana Department of Education. 2004. Grade level expectations. 29 Dec. 2007. <http://www.doe.state.la.us/ lde/saa/1915.html>.

Musser, L.M. and A.J. Malkus. 1994. The children's attitudes toward the environment scale. J. Environ. Educ. 25(3):2226.

Pivnick, J. 1994. Sowing a school garden: Reaping an environmental ethic. Green Teacher 38:7-8.

Smith, L. 2003. The integration of a formal garden curriculum into Louisiana public elementary schools. Louisiana State University, Baton Rouge, Master's Thesis.

Wakefield, J. 2001. Green lessons boost grades. Environ. Health Perspectives 109(6):A255. 